\title{
Analyzing the Moderating Effect of Perceived Brand Image in Creating Customer Loyalty: A Case of Indian Telecom Industry
}

\author{
Sasmita Pattnaik \\ Research Scholar, Siksha O Anusandhan deemed to be University, India \\ Email:sasmipattnaik@gmail.com \\ Uma Sankar Mishra \\ Professor and Head, Dept. of Management, Central University of Rajasthan, India \\ Email: usmishra@curaj.ac.in
}

\begin{abstract}
Service providers in Indian telecommunication industry are now facing lots of challenges for their sustainability in tough competition because of varying wants of customers. Provision of quality service, initiatives of public relationship programmes, and generation of timely customer satisfaction are now of major concerns. In addition to these, positioning a proper brand image in customers' mindset is equally important. The present study investigates all these factors of service business concerns to know the key determinants of achieving appropriate customer loyalty. Around 214 numbers of cell phone users were surveyed through a structured tested questionnaire in the state of Odisha, India and then all collected responses were analyzed through structural equation models. Study results showed that perception on public relation moderated by brand image has no role in creating customer loyalty. Again, after introduction of brand image as moderator, the impact of service quality on customer satisfaction becomes insignificant. However, customer satisfaction plays a major role in the variation of customer loyalty.
\end{abstract}

Key Words: Service Quality, Customer Satisfaction, Loyalty, Public Relation, Brand Image

\section{Introduction}

Now days all the Organization's activities directed towards establishing, developing and maintaining successful relationship exchanges. According to Kotler, (1987), Relationship marketing focuses on building long term relationship with the key parties in a satisfy way. In marketing theories and practices relationship constitute an important part. (Morgan \& Hunt, 1994). Relationship marketing helps to better understand and respond to customer's needs and preferences in order to build effective links with customers. It is very essential for the firm to 
differentiate themselves from the rest players to retain valuable customers for them. Loyal clients will enhance income and make proficiency to the activity of organization (Reicheld, 2001).

Loyal clients would consistently buy in spite of higher offer or rate and high addition on margin. Accordingly loyalty can give high gain to organization. The loyal clients will diminish cost spent to draw new clients. To achieve the kept up genuine edge, the telecom organizations are obliged to slice progression and to execute the best thing for the satisfaction of their customer's. So the marketing relationship plays out the fundamental part in the business of telecom (Grönroos, 2004).

Service quality works as a key factor to provide competitive edge for service organization. The customer's satisfaction and trust are controlled by the perceived quality service. The high quality service will have a positive effect on the customer satisfaction. When the customers will not obtain the quality of service which they were imagining before the buy their trust will shake which in turn makes the customer dissatisfied and this ends up in customer switch to other service provider. For making long term good trust worthy relation with the clients, the companies should provide the customers what they require and want. Brand image also play an important role in creating the satisfaction of the customers. The crucial aim of the brand and product management is to build strong brand image which in turn generate the huge short term as well as long term profit (Aaker, 1997). There is a positive effect of brand picture on the client dependability and responsibility towards the contributions of the market.

\section{Review Literature}

Due to increased competition and rapid technological innovation many industries focuses changed from financial indicators to sustain in the long run. In present scenario they tracked customer satisfaction, brand loyalty and brand image to predict the future of the companies. To increase market share they are not only acquiring new customers rather giving more importance to attract and retain customers in the long run for their survival. So the organizations with more loyal customers gain more competitive advantage due to their repeat purchase, recommendation to others, their emotional attachment and tolerance to price variance. The importance of customer relationship management has been increasing tremendously in this competitive era. The building of good relationship with customers provides organization competitive advantage (Reichheld, 1993). For this Organizations put their profit to enhance public relation, which later on provide financial gain to them.

\subsection{Customer Satisfaction}

In marketing customer satisfaction used widely. It shows whether merchandise provide by an organization fulfill client's expectation. Customer satisfaction can be described as the total 
number of customers who experienced satisfaction with a firm due to their products or services performed more than their expectation. (Wikipedia)

Satisfaction is, "The buyer's cognitive state of being adequately or inadequately rewarded for the sacrifices he has undergone", Howard and Sheth (1969)

Oliver (1981) explained Customer Satisfaction as, "the summary psychological state resulting when the emotion surrounding and expectations is coupled with the consumers' prior feelings about the consumption experience".

"Customer/consumer satisfaction is an evaluation that the chosen alternative is consistent with prior beliefs with respect to that alternative" (Engel and Blackwell, 1982)

It is defined as, “the consumer's response to the evaluation of the perceived difference between previous expectations and the actual performance of the product/service as perceived after its consumption" (p.204) (Tse and Wilton, 1988). Berry and Parsuraman (1991) in their paper highlighted customer satisfaction depends upon the customer service provision in a qualitative way by all organization and they take it seriously. It reflects after consumption response about the products by customers.

Anton (1996) give more elaboration: "customer satisfaction as a state of mind in which the customer's needs, wants and expectations throughout the product or service life have been met or exceeded, resulting in repurchase intention and loyalty".

From customer satisfaction model, it was find out that service quality influences customer satisfaction (Uddin, Akhter, 2012).

Many researchers' exhibits there present some relationship between the service quality variables with customer satisfaction. It also comes to notice that customer satisfaction and loyalty have positive relationship. Further study in this field shows service quality attributes helps in increasing level of satisfaction and the later creates loyalty among customers (Bhatt, 2015).

To analyze the connection between Customer loyalty, Service quality and Customer Satisfaction of Taiwan Commercial swim clubs Yi-Chin Liu conducted a study in Taiwan's four regions. For this study he collected 767 samples using convenience technique. According to the findings of this study there was a major difference of customer satisfaction and client loyalty exists.

Among customer loyalty, service quality and customer satisfaction factors strong relationship exists. All these variables interlinked with each other. All service quality attributes validate relationship with customer satisfaction in a positive manner (Siddiqi, 2011).

Customer satisfaction goes probably as mediator between organization perceived service quality estimations and customer loyalty. Perceived service quality go about as precursors of purchaser 
satisfaction and no affecting client lead plainly (Turk and Avcilar, 2009). Different appraisals saw a solid connection exists between customer satisfaction and customer's repurchase assumptions. Additionally Customer satisfaction is a basic factor of customer loyalty. If shopper satisfaction impact customer loyalty unequivocally it prompts customer repurchase objective and they additionally prescribe the thing to different clients (Mittal and Kamakura, 2001; Zeithaml et al., 1996; Reichheld and Sasser, 1990).

\subsection{Customer loyalty}

According to Oliver (1997) loyalty depends on situational influence. The author describes brand loyalty as "a deeply held commitment to repeat purchase or re-patronize a preferred product/service consistently in the future, thereby causing repetitive same brand or same brand set purchasing, despite situational influences and marketing efforts, having the potential to cause switching behavior"

Consumer mostly affected by attitudinal dimension of loyalty in service market. This attitude generates different emotions among clients it also affect their mentality towards loyalty for a service or product. (Hallowell, 1996)

Loyalty among consumers is basically a situation, where they buy the same product or service repeatedly from the manufacturer rather buying it from somewhere else. (AMA).

Dick and Basu (1994) bring new approaches related to the loyalty measurement. In their study they focus on attitude of various purchasers and the factors that enable it for more purchase of the same items. According to them loyalty can be an outcome of relative attitudes of customer's for a product and re-buy behavior. According to Kuhen (1962), Loyalty is the purchase of the same brand again and again.

\subsection{Service Quality}

Service quality basically measures how well an organization fulfills customer's expectation. Every customer posses their own yardsticks to measure services they received from companies. A business with a high level of service quality is able to meet customer requirements which provide them economical advantages in their respective industries. This service quality provides long term economic benefit and increases profitability. Organization achieve overall service quality by improving its all processes, resolving problems quickly, having a good measurement tool and measuring total outcomes and level of satisfaction.

Service organization previously emphasized on their products are gradually focus on customers and relationship marketing, they basically make customer loyal. According to Gilmore customer oriented behavior is very important for service firms which ensure better quality. 
Berry and Parsuraman (1991) in their paper highlighted customer satisfaction depends upon the customer service provision in a qualitative way by all organization and they take it seriously. It reflects after consumption response about the products by customers.

According to Akbar and Prevaez (2009) in between trust, service quality, customer loyalty and satisfaction an important and positive relationship present. In their study they first examine the relationship of customer satisfaction that mediates customer loyalty and service quality dimensions perceived by customer directly or indirectly through a model. In another model they examined the link or any direct connection prevails in between customer loyalty and trust. From this study they identified a path from perceived service quality to satisfaction among customers and from satisfaction to trust and then loyalty. Customer satisfaction intervene perceived service quality dimensions and customer loyalty is the outcome of the study.

\subsection{Brand Image}

"A brand is a term, design, name, symbol or any other features that distinguish one company's product to the others" (American Marketing Association, 2013).

"A brand is, tangible and intangible, practical and symbolic, visible and invisible under conditions that are economically viable for the company". (Kapferer, 1986)

According to Robert and Dowling in 2002 Brand is a valuable intangible asset of the companies, is difficult to copy that's why it is able to provide sustainable competitive advantage. It is based on multiple factors and various qualities perception. Product evaluations are influenced by brand images. This image effects on products can be explained by consumers' levels of involvement, knowledge, usage and satisfaction.

In today's competitive market a must have forte for a company is branding. Branding is an all important factor in attracting customers. Customers tend to overlook a few shortcomings if any of a product, if the product belongs to a well known brand. People also feel that buying a product from a well known and positive brand is less of a risk (Kim et al, 2008). According to Forsido (2012), brand image, product involvement and customer satisfaction determined brand loyalty.

A study by Neupane (2015) asserted that the overall image of a brand image affects on satisfaction of customers in majorly. Similarly, the brand's overall image has significant results on customer's overall loyalty intention; in addition to this satisfaction among customers have key and affirmative effect on loyalty intention of consumers in an organization.

According to Keh and Xie, brand image influence customer loyalty largely. It also acts as a moderator variable in between customer loyalty and customer perception about public relation, Bartikowski et. al. Tsai and Yang in their research explained, that corporate reputation can be explained in three ways, these are corporate image, citizenship and how management are credible enough to showcase their product fairly. If an organisation make strong brand image it leads to strong customer loyalty, Nguyen and Leblanc. 
The relationship between brand image and customer satisfaction has been studied broadly. Theoretically it can be found that service quality and customer satisfaction will lead to customer loyalty. Brand image has a strong impact on customer perceived service quality and customer satisfaction. Brand image and its impact on customer loyalty need to be tested more. It is therefore relevant to study further to explore the impact of brand image on consumer behavior.

The connection between brand image and consumer loyalty has been contemplated comprehensively. Hypothetically it tends to be discovered that quality of service and user satisfaction will prompt client loyalty. Brand image emphatically affects client service quality and customer satisfaction. Brand image and its effect on client loyalty should be tried more. It is consequently applicable to concentrate further to investigate the effect of brand image on buyer purchase behavior.

\subsection{Public Relation}

Loyal customers will undoubtedly repurchase comparable brand, spread positive information and prepared to pay extra for better assistance. Advertising are described as the administration of correspondence between an affiliation and its public (Gruning and Hunt, 1984). According to Ledingham and Bruning (1998) PR is a relationship management. While Cutlip et al. in 2006 portray PR is the organization stir that develops and keeps up ordinarily significant associations between an organization and general society's on whom its success and dissatisfaction depends.

Higher customer loyalty generates higher revenue through taking relatively higher prices as compared to competitors and also increase market share. Public relations are important promotional tools, which help in building good relation with public by favorable publicity, enhancing corporate image and minimizing the effect of unfavorable activities.

Public is another important factor on which organization's success or failure depends. There are so many works have been done related to customer loyalty but the relationship between customer loyalty and public relation needs more attention. When Organization plans to cultivate PR and fulfill commitment consumers become more loyal to organization (Coombs, 2001). Very few researches done to identify the factors that has positive effect on customers public relation perceptions practices. This inconsistent result might be caused by moderator like brand association. Negative brand image of an organization reduce the effectiveness of PR.

Bartikowski, Walsh and Beatty expound brand image as an moderator variable between client perception of public relation and loyaty. As per Hseih and Li (2008) the effect of PR perception on client loyalty is more grounded and more critical when the brand image is positive and on the off chance that it isn't positive the impact of PRP on client dedication is unimportant. 
Based on the previous research outcomes, following research hypotheses were formulated.

H1: $_{1}$ Perceived Service Quality (PSQ) significantly impacts Customer satisfaction (CS) in Indian tele-service sector.

H2: Customer Satisfaction (CS) has significant impact on Customer Loyalty (CL).

H3: Perceived Public Perception (PRP) has significant impact on Customer Loyalty (CL).

H4: Brand Image (BI) has significant moderation effect on the relationship between PSQ and CL, mediated by CS.

H5: Brand Image (BI) has significant moderation effect on the relationship between PRP and CL. Figure 1 represents the conceptual model considered in current research.

Fig. 1: Conceptual Model

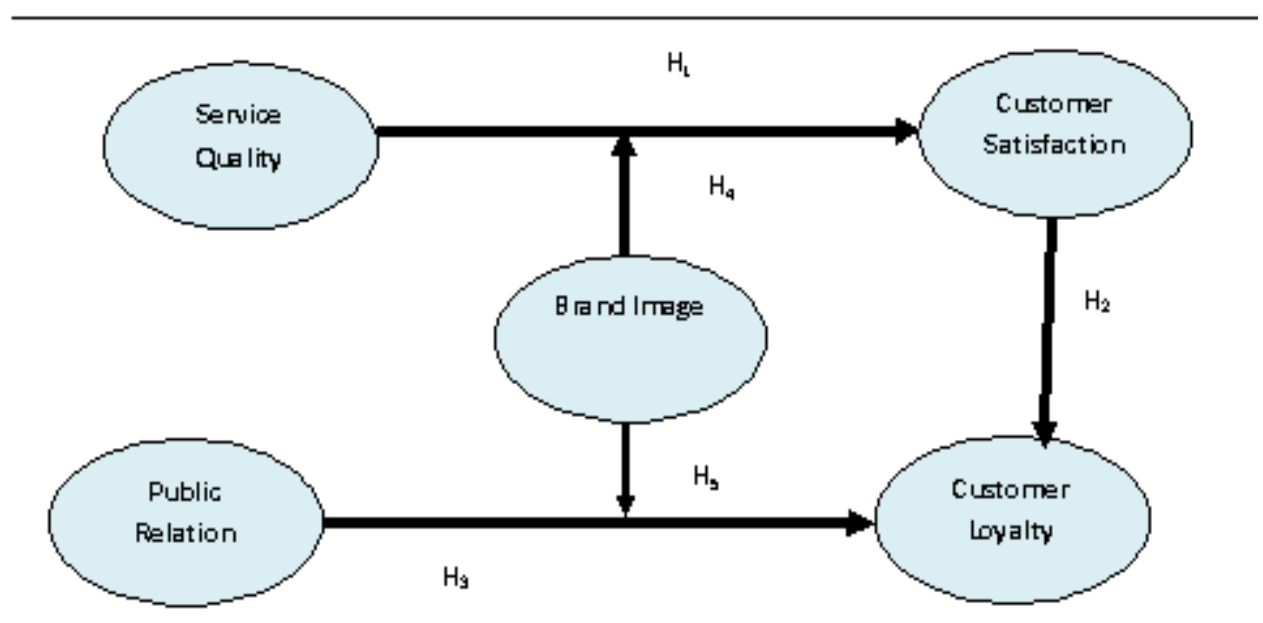

\section{Research Design and Methodology}

The current research study was more based on causal type of design with the purpose to get empirical support on mediating and moderating effects of customer satisfaction and brand image respectively, giving outcome of loyalty from service quality and perceived public relations. Responses were collected from 214 numbers of cell phone service users covering 13 telecom districts of Odisha state in India. Convenient sampling method was used to select these respondents. A structured questionnaire got designed considering all major research constructs. Most of the questionnaire items were referred from past literatures (Parasuraman, A., Zeithaml, V. and Berry, L.L. (1988); Hsieh A. T. \& Li C. K. (2007); Simon Gyasi Nimako et al (2012); Chiu S. K. K. (2010); Gi-Du, K. \& James, J. (2004); Xuan Zhang \& Yuanguan Feng (2009)). 
All the primary data were collected in Likert scale (7 point) format. Before analyzing the final data, test on reliability and validity analysis of survey questionnaire were done after pilot survey (Table 1 and 2).

Table 1: Reliability Analysis Outcomes(Cronbach's alpha score)

\begin{tabular}{lccccc}
\hline Variables: & PSQ & CS & CL & PRP & BI \\
Score: & 0.81 & 0.84 & 0.83 & 0.83 & 0.85
\end{tabular}

In order to know the degree of internal consistency among research items under common constructs reliability analysis was done through Cronbach's alpha value observation, and in this present study all the values were found to be more than 0.80 with respect to respective research constructs (Table 1).

Table 2: Measurement Model test inclices of Goodness of Fit

\begin{tabular}{lccccc}
\hline Variables & CMIN/df & GFI & CFI & RMSEA & AVE \\
PSQ & 2.09 & 0.983 & 0.983 & 0.072 & 0.83 \\
CS & 2.017 & 0.986 & 0.991 & 0.006 & 0.82 \\
CL & 1.84 & 0.973 & 0.981 & 0.063 & 0.80 \\
PRP & 1.97 & 0.921 & 0.965 & 0.057 & 0.81 \\
BI & 1.39 & 0.985 & 0.989 & 0.067 & 0.84
\end{tabular}

Then, Confirmatory Factor Analysis (CFA) was conducted to check the construct validity of data collected and the derived measurement models' output results are reflected in table 2. It was seen that all goodness of fit indices of measurement models was in the acceptable range as per Hair et al., 2006. Final analysis and interpretation were done through structural equation modeling approach using Amos 21 software package.

\section{Results and Discussion}

The basic purpose of this research study was to investigate the moderating role of brand image as perceived by telecom service users among the relationship of perceived service quality, perceived public relation and customer loyalty. However, since most of the past studies have 
found customer satisfaction can be the mediating construct in-between service quality and loyalty, in the present study that has also been analyzed (Fig.1). Therefore, to study the complex cause-effect relationships including five latent variables, development and fitting of structural equation models (SEM) were undertaken and interpreted.

Figure 2: Structural Equation Model showing cause-effect relationship between without Mbderator

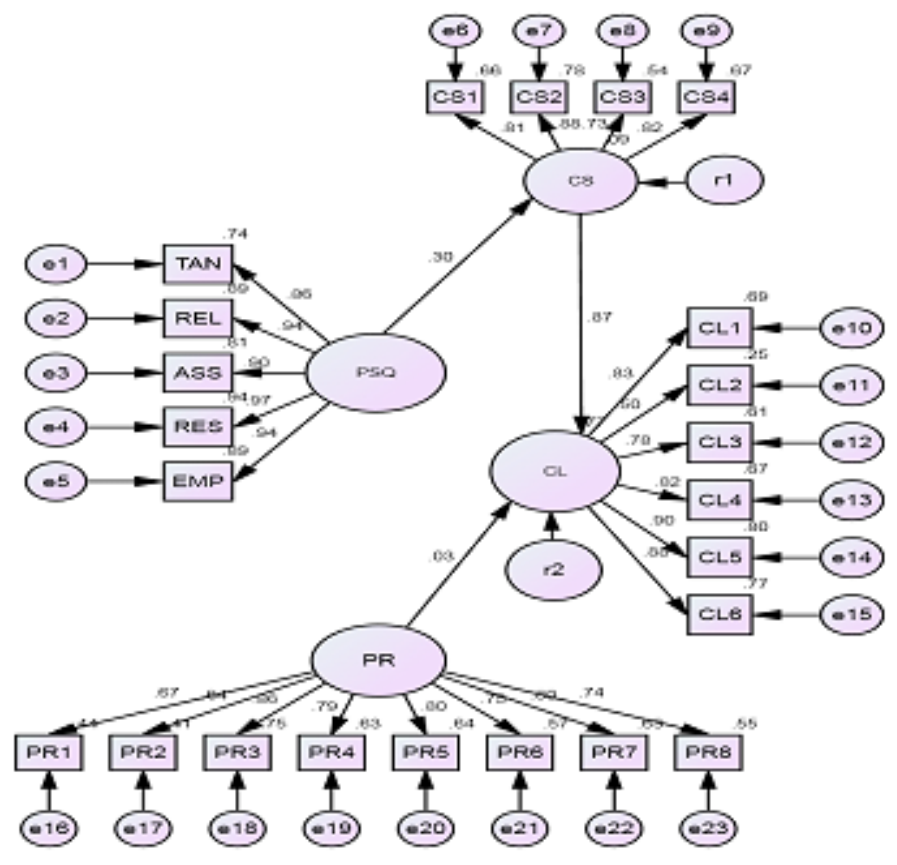

Figure 2 highlights the structural path diagram of SEM, showing the linkages among PSQ, PRP, CS, and CL. PSQ was having 5 observed variables, viz, tangibility, reliability, assurance, responsiveness, and empathy. Again, CS, CL and PRP consist of 4, 6 and 8 measurement items respectively.

\begin{tabular}{|c|c|c|c|c|c|c|c|c|c|c|c|c|}
\hline Hypathesis & & Paff & & 6 & B & S.E. & C.R & $\mathbf{P}$ & CMIN/d & GFI & CFI & RMSEA \\
\hline $\mathrm{H}_{1}$ & PSQ & ? & $\mathrm{cs}$ & 0.295 & 0.296 & 0.071 & 4.137 & 0.000 & & & & \\
\hline $\mathrm{H}_{1}$ & $\mathrm{cs}$ & $?$ & CL & 0.875 & 0.932 & 0.078 & 12.011 & 0000 & 2996 & 0.901 & 0911 & 0.078 \\
\hline $\mathrm{H}$ & PRP & $?$ & CL & 0.025 & 0.022 & 0.038 & $05 \pi 0$ & 0569 & & & & \\
\hline
\end{tabular}


Table 3 describes the SEM fitness results in the absence of moderator (BI) and it was seen that the impacts of PSQ on CS $(\beta=0.295, \mathrm{p}<0.01)$ and CS on CL $(\beta=0.875, \mathrm{p}<0.01)$ were significant. However, the effect of PRP on CL was insignificant $(\beta=0.28, p>0.05)$. Again, the overall fitness of the model was acceptable (GFI \& CFI > 0.9, RMSEA < 0.08).

The following figure 3 represents the structural path diagram of SEM taking brand image (BI) as moderator, in the above mentioned relationship.

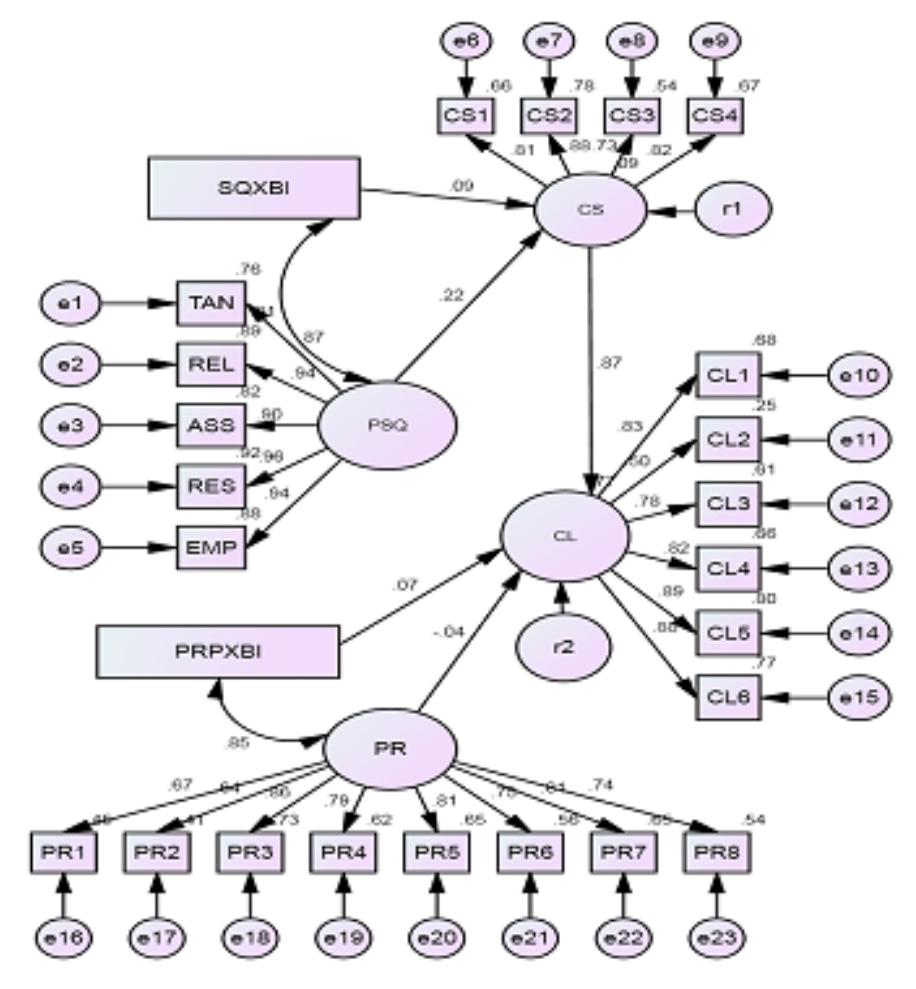

As table 4 described, an appropriate model fit achieved even after introduction of BI as moderator $(\mathrm{CFI}=0.901$, RMSEA $=0.079)$. Again, the impact of moderated PSQ on CL through CS became significant as the p-level of the relationship between PSQ and CS is higher than 0.05 after taking moderator. However, there was no moderation effect of brand image on the relationship between PRP and CL. 
Tahle 4: SEM results showing moderating effects of $\mathrm{BI}$

\begin{tabular}{|c|c|c|c|c|c|c|c|c|c|c|c|c|}
\hline Hypdthesis & & th & & i & B & SE. & C.. $\mathbf{R}$. & $\mathbf{P}$ & cMUN/af & GFI & CFI & RMSEA \\
\hline $\mathrm{H}_{1}$ & $\mathrm{PSQ}$ & ? & CS & 0.219 & 0.220 & 0.122 & 1.798 & 0.072 & & & & \\
\hline $\mathrm{H}_{1}$ & $\mathrm{CS}$ & ? & CL & 0.874 & 0.927 & 0.077 & 11989 & 0.000 & & & & \\
\hline $\mathrm{H}_{1}$ & PRP & ? & CL & .036 & .031 & 0078 & .394 & 0.693 & 3096 & 0891 & 0901 & 0.079 \\
\hline $\mathrm{H}$. & PSQXBI & ? & CS & 0.091 & 0.009 & 0.012 & 0.757 & 0.049 & & & & \\
\hline $\mathrm{H}_{2}$ & $\mathrm{PRPXBI}$ & ? & CL & 0.072 & 0.008 & 0.009 & 0.823 & 0.410 & & & & \\
\hline
\end{tabular}

Therefore, it may be concluded that although service quality affects the degree of loyalty through customer satisfaction, when brand image got introduced service quality does not play a major role in creating customer satisfaction.

\section{Managerial Implications}

The current empirical research in Indian telecom service market corroborates the fact that service providers should be conscious in satisfying exact wants of customers to make them more loyal. Quality service has to be provided to achieve this target. In increasing brand image of teleservice products, although service quality becomes immaterial in generating customer satisfaction, it may have some other implications for sustainability of business. Programmes of public relations may be conducted to improve the awareness level among customers. These PR programmes may not play a major role to satisfy the core need of customers for making them loyal. Appropriate promotional plans may be designed and implemented for improving the brand values in the mindset of cell-phone service customers.

\section{REFERENCES}

[1] Morgan, R.M. \& Hunt, S.D., "The Commitment-Trust Theory of Relationship Marketing”, Journal of Marketing, 58, (1994), 20-38

[2] Kotler, P. “Strategic Marketing for Nonprofit Organizations”, Prentice-Hall, (1975).

[3] Reichheld, F. F., "The loyalty effect: The hidden force behind growth, profits and lasting value”, Cambridge, MA: Harvard Business Press., (2001).

[4] Reichheld, F.F., "Loyalty-Based Management”, Harvard Business Review, 2, 64-73, (1993).

[5] Gronroos C., "The relationship marketing process: communication, interaction, dialogue, value", Journal of Business \& Industrial Marketing, Vol. 19 No. 2, (2004), pp. 99-

113. https://doi.org/10.1108/08858620410523981

[6] Aaker, J. L., “Dimensions of Brand Personality”, Journal of Marketing Research, 34(3), (1997),pp.347-356. http://dx.doi.org/10.2307/3151897 
[7] Howard John, A., \& Sheth, J.N., “The Theory of Buyer Behaviour”, New York: John Wiley (1969).

[8]Oliver, R.L., "Measurement and evaluation of satisfaction processes in retail settings, Journal of Retailing”, Vol.75, (1981), pp.25.48.

[9] Oliver, “Whence consumer loyalty?”, Journal of Marketing, 634, (1999)pp 33-44.

[10] Engel James, F. \& Blackwell, R.D., “Consumer Behaviour”, New York: Holt, Rinehart, (1982).

[11] Tse, David K. \& Wilton, P.C, “Models of Consumer Satisfaction: An Extension”, Journal of Marketing Research, May 25, (1988), pp.204-212.

[12] Berry, L.L. and Parasuraman, A., "Marketing Services: Competing through Quality", The Free Press, New York, NY: p.31, (1991).

[13] Anton, J., "Customer Relationship Management: Making Hard Decisions with Soft Numbers, Englewood Cliffs”, NJ,Prentice-Hall: p.73., (1996).

[14] Uddin, M. B.; Akhter, B., "Customer satisfaction in mobile phone services in Bangladesh: a survey research”, Management \& Marketing X(1): 20-36. (2012).

[15] Bhatt, J. B, “A Study on Customer Satisfaction in Indian Retail Banking”, RESEARCH HUB - International Multidisciplinary Research Journal, (2015) ,2(2).

[16] Liu, Y. C. An Analysis Service Quality, Customer Satisfaction and Customer loyalty of commercial swim clubs in Taiwan, Dissertation Project, September 2008, United States Sports Academy, (2008).

[17] Siddiqi, K. O., "Interrelations between Service Quality Attributes, Customer Satisfaction and Customer Loyalty in the Retail Banking Sector, Bangladesh, International Journal of Business and Management, (2011), 6(3).

[18]Turk, Z. \& Avcilar, M.Y., "The effects of perceived service quality of audit firms on satisfaction and behavioral intentions: A Research on the Istanbul stock exchange listed companies”, Research Journal of Business Management, 2(1), (2009) ,pp36-46.

[19] Mittal, V. \& Kamakura, W.A. , "Satisfaction, repurchase intent, and repurchase behavior: investigating the moderating effect of customer characteristics" , Journal of Marketing Research, 38, (2001), 131-42. 
[20] Zeithaml, V.A., Berry, L.L., \& Parsuraman, P. "The behavioral consequences of service quality”, Journal of Marketing, 60 (2), (1996), 31-46.

[21] Reichheld, F.F. \& Sasser, W.E., “Zero defections: quality comes to service.”, Harvard

Business Review, 68 (5), (1990), 105-11.

[22] Oliver, R. L. , "Satisfaction: a behavioral perspective on the consumer", 1st ed. New York: McGraw- Hill 432 p. ISBN-10: 0071154124. (1997).

[23] Hallowell, $R$. The relationships of customer satisfaction, customer loyalty and profitability: An empirical study, International Journal of Service Industry Management, 7 (4), (1996), pp 27 37.

[24] Dick AS, Basu K , “Customer loyalty: toward an integrated conceptual framework”, Journal of Academy of Marketing Sciences, 22(2), (1994), pp 99-113.

[25] Kuehn, A., "Consumer brand choice as a learning process" Journal of Advertising Research, 2, (1962) pp 10-17.

[26] Gilmore, J. H., \& Pine, B. I. I., "Customer experience places: the new offering frontier”, Strategy \& Leadership, 30, (2002). 4-11.

[27] Berry, L.L.\& Parasuraman, A. , “Marketing Services: Competing through Quality”, New York, NY: The Free Press, p.31, (1991).

[28] Akbar,M. M, \& Parvez, N. , "Impact of service quality, trust, and customer satisfaction on customer loyalty”, ABAC Journal, 29 (1), (2009), pp24-38.

[29] Kapferer, J-N., "Beyond positioning, retailer's identity", Esomar Seminar Proceedings, Brussels, 4-6 June, (1986) , pp.167-76.

[30] Roberts, P. W. \& Dowling, G. R., "Corporate reputation and sustained superior financial performance”, Strategic Management Journal, 23, (2002), 1077-1093.

[31]Kim, KH., Kim KS., Kim DY., Kim JH., Kang SH. , "Brand equity in hospital marketing”, Journal of Business Research, 61(1), (2008), Pp 75-82.

[32]Forsido M. Z., “Brand loyalty in Smartphone”, Master Thesis (2012). 
[33]Neupane, $R$. , "The effects of Brand Image on Customer Satisfaction and Loyalty intention in retail super market chain in UK”, International Journal Social Sciences Management, 2(1), (2015), pp 9-26.

[34] Keh HT, Xie Y, "Corporate reputation and customer behavioral intentions: The roles of trust, identification and commitmen”, Industrial Marketing Management 38: (2009) ,pp732- 742

[35]Tsai WC, Yang IWF, "Does image matter to different job applicants? The influences of corporate image and applicant individual differences on organizational attractiveness", International Journal of Selection and Assessment, 18: (2010), pp 48-63.

[36]Nguyen $N$, Leblanc $G$, "Corporate image and corporate reputation in customers' retention decisions in services", Journal of retailing and Consumer Services 8: (2001), pp227-236.

[37] Gruning, J. \& Hunt, T. "Theories of Publics and communication Behavior: Models of Public Relations”, Managing Public Relations, (1984).

[38]Bruning \& Ledingham, “ Using cultivation strategies to manage publicrelationships.,www.pr ismjournal.com. (2000).

[39] Cutlip, S. M., Center, A. H., \& Broom, G. M., “Effective public relations”, (9th ed.). Upper Saddle River, NJ: Pearson Prentice Hall, (2006).

[40]Coombs, W.T. \& Holladay, S.J., "An extended examination of the crisis situation: A fusion of the relational management and symbolic approaches" Journal of Public Relations Research, 13, ,(2001). pp321-340.

[41] Bartikowski B, Walsh G, Beatty SE, "Culture and age as moderators in the corporate reputation and loyalty relationship. Journal of business research 64: (2011), pp966-972.

[42] Hsieh A. T. \& Li C. K., "The moderating effect of brand image on public relation perception and customer loyalty”, Marketing Intelligence \& Planning , 26 (1), (2007), pp26-42.

[43]Chiu S. K. K. et.al. Power of branding on internet service providers, The Journal of Computer Information Systems; Spring, 50, 3; (2010), pp: 112.

[44] Gi-Du, K. \& James, J., "Service quality Dimensions: An Examination of Grönroos' Service Quality Model, Managing Service Quality”, Vol 14(4), (2004), pp. 266-277.

[45] Hair, J. F., Black, W. C., Babin, B. J., Anderson, R. E., \& Tatham, R. LMultivariate data analysis (Vol. 6).Upper Saddle River, NJ: Pearson Prentice Hall. (2006). 
[46]Hsieh A. T. \& Li C. K., "The moderating effect of brand image on public relation perception and customer loyalty, Marketing Intelligence \& Planning ”, 26 (1), (2007), pp26-42.

[47]Parasuraman, A., Zeithaml, V. and Berry, L.L, ".SERVQUAL: A Multiple-item Scale for Measuring Consumer Perceptions of Service Quality”, Journal of Retailing, Vol. 64, spring, (1988) , pp: 12-40.

[48] Simon G. N., Foresight K. A., Francis D. and Veronica A. "Confirmatory factor analysis of service quality dimensions within mobile telephony industry in Ghana”, Electronic Journal Information Systems Evaluation, Vol 15, Issue 2, (2012), pp. 197-215

[49] Xuan Z. and Yuanguan F., "The Impact of Customer relationship Marketing Tactics on Customer Loyalty - within Sweden Mobile Telecommunication Industry”, Master's Dissertation in International Marketing, Halmstad University, (2009). 